\title{
Prostate Cancer cNX TNM Finding v7
}

National Cancer Institute

\section{Source}

National Cancer Institute. Prostate Cancer CNX TNM Finding v7. NCI Thesaurus. Code C89223.

Prostate cancer in which the regional lymph nodes cannot be assessed. (from AJCC 7th Ed.) 